\title{
Dukungan Orangtua Terhadap Motivasi Berprestasi Siswa SKOI Kalimantan Timur Dalam Mengikuti Pembelajaran Pendidikan Jasmani
}

\author{
Nanda Alfian Mahardhika*1, Jeane Betty Kurnia Jusuf, Galih Priyambada \\ ${ }^{1}$ Program Studi Pendidikan Olahraga, Fakultas Keguruan dan IImu Pendidikan, Universitas \\ Muhammadiyah Kalimantan Timur. Jalan Ir. H Juanda No. 15, Samarinda, Kalimantan Timur \\ 75124, Indonesia. \\ ${ }^{*}$ Corresponding Author. Email: nam791@umkt.ac.id
}

\begin{abstract}
Abstrak
Penelitian ini untuk mengetahui dukungan orang tua terhadap motivasi berprestasi siswa SKOI Kalimantan Timur. Penelitian ini merupakan penelitian deskriptif kuantitatif. Metode yang digunakan survei menggunakan instrumen angket yang berikan orang tua siswa dan siswa SKOI yang berjumlah 50 orang. Populasi penelitian ini adalah seluruh orang tua siswa dan siswa SKOI Kalimantan Timur. Dalam penelitian ini menggunakan teknik sampling jenuh dengan sampel seluruh anggota populasi sebagai sampel. Teknik analisis statistik deskriptif yang dituangkan dalam bentuk persentase. Rencana penelitian ini dilaksanakan selama 6 bulan. Hasil penelitian ini adalah dukungan orang tua siswa termasuk dalam kategori sangat baik yaitu sebesar 93,4 \%. Motivasi berprestasi siswa termasuk kedalam kategori sangat baik yaitu sebesar $97,2 \%$.
\end{abstract}

Kata Kunci: orang tua, motivasi berprestasi, siswa, SKOI, Kalimantan Timur

\section{Parental Support for the Achievement Motivation of SKOI Students in East Kalimantan in Attending Physical Education Learning}

\begin{abstract}
The aim of this research is to examine the effect of parent's supports toward the needs of achievement possessed by students of Sekolah Khusus Olahraga Internasional (SKOI) in Samarinda city. This research method used in this research is descriptive qualitative method. The instrument of research was the questionnaires shared to the population of 50 SKOI students as well as their parents. The saturated sample research technique was used to the all over population as the sample. The method of this research was presented in the percentage term and done within a six-months period. The result of this research is that the support of parent's students gained a positive trend with $93.4 \%$ and the needs of achievement of the students are very good (accounted for 97,2\%).
\end{abstract}

Keywords: parents, the needs of achievement, students, SKOI, Kalimantan Timur

\section{PENDAHULUAN}

Pendidikan jasmani merupakan suatu pendidikan yang mengajarkan anak untuk hidup sehat dan terampil dalam berolahraga. Seseorang yang masuk sekolah, wajib mengikuti pelajaran pendidikan jasmani, karena dengan pendidikan jasmani karakter anak bisa terbentuk. Perencanaan pendidikan jasmani dilakukan secara seksama untuk memenuhi perkembangan, pertumbuhan, dan kebutuhan perilaku setiap anak. Maka pendidikan jasmani bukan hanya ditujukan untuk mengembangan psikomotor, akan tetapi juga mengembangkan kemampuan kognitif dan afektif peserta didik. (Paramitha \& Anggara, 218: 42)

Proses pendidikan jasmani hendaknya disadari oleh guru dan siswa. Beberapa siswa mengatakan bahwa mereka belum pernah melakukan tes kebugaran jasmani sehingga tidak 
tahu bagaimana tes kebugaran jasmani tersebut. Tugas dan kewajiban guru pendidikan jasmani adalag mengatur, mengarahkan dan membimbing peserta didik untuk mencapai seperangkat daripada tujuan pendidikan jasmani dan bisa menciptakan suasana belajar yang bisa menyenangkan dengan melibatkan pesera didik aktif dalam mengikuti setiap pertemuan/setiap proses pembelajaran yang dilaksanakan oleh guru.

Kegiatan olahraga menjadi bagian yang tidak terpisahkan dari semua aspek kehidupan manusia, karena dengan kegiatan jasmani bisa menjadi yang penting dalam menghadapi tantangan hidup dan kegiatan sehari-hari. Oleh karena itu, guru sebagai seorang pendidik harus memiliki peranan yang penting, karena dalam melaksanakan pembelajaran efektif guru hendaknya bisa menerapkan strategi pembelajaran yaitu memprioritaskan daripada tujuan pembelajaran, mengevaluasi kegiatan pembelajaran dan merencanakan, memotivasi serta pengendalian jiwa peserta didik, dan juga guru dapat menentukan sikap sehingga bisa menghasilkan siswa yang berwawasan positif terhadap perkembangan dirinya sendiri/peserta didik. Menjadi guru pendidikan jasmani yang profesional tidak semudah yang dibayangkan banyak orang selama ini, salah persepsi menganggap guru pendidikan jasmani hanya bermodal peluit dan bola di sekolah. (Syahrin, Amiruddin, dan Bustamam, 2017: 77). Dikalangan guru pendidikan jasmani sering ada anggaapan bahwa pendidikan jasmani dapat dilaksanakan seadanaya, sehingga pelaksanaannya cukup dengan cara menyuruh anak pergi ke lapangan, menyediakan bola sepak untuk laki-laku dan bola voli untuk perempuan, guru tinggal mengawasi dari pinggir lapangan.

Menurut Suryobroto, A.S ( 2004: 63) bahwa sebagai mata pelajaran khas yang menitikberatkan perhatian pada ranah jasmani dan psikomotor, tetapi tidak mengabaikan ranah kognitif dan afektif, pelajaran pendidikan jasmani harus mencakup materi (1) kesadaran akan tubuh dan gerakan, keterampilan motorik dasar, (2) kebugaran jasmani, aktivitas jasmani, seperti permainan, gerakan ritmik tari dan senam, (3) aktivitas pengkondisian tubuh, modifikasi permainan dan olahraga, dan keterampilan hidup di alam terbuka, (4) olahraga perorangan, berpasangan dan tim, (5) keterampilan hidup mandiri di alam terbuka, dan (6) gaya hidup aktif dan sikap sportif. Secara garis besar bahwa pendidikan jasmani merupakan bagian tak terpisahahkan dari pendidikan umum. Tujuannya adalah untuk membantu anak tumbuh dan berkembang secara wajar sesuai dengan tujuan pendidikan nasional, yaitu menjadi manusia Indonesia seutuhnya. Pencapaian tujuan tersebut berpangkal pada perencanaan pengalaman gerak yang sesuai dengan karakteristik anak.

Pada hakikatnya pendidikan jasmani adalah proses pendidikan yang memanfaatkan aktivitas fisik untuk menghasilkan perubahan holistic dalam kualitas individu, baik dalam hal fisik, mental dan emosional. Pendidikan jasmani memperlakukan anak sebagai sebuah kesatuan utuh, makhluk total, dan sebagai seseorang yang terpisah kualitas fisik dan mentalnya.

Tujuan dari pendidikan jasmani adalah untuk meningkatkan taraf kesehatan anak yang baik dan tidak bisa disangkal pula ada yang mengatakan bahwa tujuan pendidikan jasmani adalah untuk meningkatkan kebugaran jasmani. Dengan demikian proses pembelajaran pendidikan jasmani dapat membentuk karakter yang kuat untuk siswa, baik fisik, mental maupun sosial sehingga dikemudian hari diharapkan siswa memiliki budi pekerti yang baik, bermoral, serta mandiri dan bertanggung jawab. Dalam setiap pembelajaran, jika siswa tidak berbuat sesuatu yang seharusnya dikerjakan, pada perlu diteliti sebab akibatnya, karena hal itu bisa berdampak pada perubahan energi dan tidak terangsang afeksinya untuk melakukan sesuatu. Dalam keadaan seperti itu perlu ditumbuhkan motivasi pada diri anak/siswa tersebut.

Setiap siswa/anak memiliki motivasi sendiri-sendiri dalam mengikuti pembelajaran pendidikan jasmani, apalagi di Sekolah Khusus Olahraga Internasional (SKOI) ini bahwa semua siswanya merupakan atlet junior/remaja yang diharapkan mampu berprestasi di akademik maupun non akademik. Sehingga dalam proses pembelajaran pendidikan jasmani guru tidak akan susah dalam memberikan materi pembelajaran. Siswa yang memiliki bakat olahraga di wilayah Kalimantan Timur ini semua diberikan beasiswa untuk mengikuti atau menempuh studi di Sekolah Khusus Olahraga Internasional Kalimantan Timur. Karena penyelenggaraan pendidikan Bakat Istimewa Olahraga pada dasarnya sudah tercantum dalam UUD 1945 dan UU No. 20/2003 tentang Sistem Pendidikan Nasional. 
Melalui program pendidikan Bakat Istimewa Olahraga ini diharapkan potensi peserta didik yang selama ini belum dikembangkan secara optimal, akan tumbuh dan menunjukkan kinerja yang baik. Selain itu, kedepannya peserta didik tersebut akan mampu dan harapannya bisa berkontribusi terhadap kehormatan Bangsa dan Negara di kancah Internasional melalui olahraga dan juga akademik anak SKOI tidak tertinggal dengan peserta didik di sekolahan umum. Peran orang tua dalam memotivasi anaknya juga diperlukan, karena orang tua adalah tempat dimana anak bisa tumbuh kembang dan berinteraksi dengan lingkungan. Orang tua selalu berada dan menjadi tempat sharing dengan anak, kaitannya dalam proses memotivasi anaknya untuk terus berprestasi. Motivasi sangat diperlukan dalam proses belajar, karena jika seseorang tidak memiliki motivasi akan mengalami kesulitan dalam melakukan aktivitas belajar.

Menurut Lailatul (2008: 64) mengatakan bahwa orang tua bertanggung jawab atas keberhasilan pendidikan anak dan sekolah hanya bertugas membantu orang tua dalam mendidik anak tersebut. Tanggung jawab orang tua atas proses belajar anak disekolah tersebut direalisasikan dengan menggunakan cara-cara yang dirasakan akan membantu kegiatan belajar anak.

Dukungan orang tua memiliki pengaruh psikologis yang besar terhadap kegiatan belajar anak. Dengan adanya dukungan orang tua, anak akan lebih giat dan lebih bersemangat dalam belajar karena ia tahu bahwa bukan dirinya sendiri saja yang berkeinginan untuk maju, akan tetapi orang tuanyapun demikian. Sebab baik buruknya prestasi yang dicapai oleh anak akan memberikan pengaruh dalam perkembangan pendidikan selanjutnya. (Rosyidah, U.M., 2017:138). Motivasi belajar dapat timbul karena faktor instrinsik, berupa keinginan berhasil, kebutuhan belajarm cita-cita masa depan, sedangkan faktor ekstrinsik adalah adanya penghargaan dalam belajar. Dalam meningkatkan prestasi siswa orang tua perlu meningkatkan peranannya sebagai Provider yaitu dalam menyediakan tempat belajar, memberitahu cara mengatur jadwal anak, dan menandatangani buku PR, dll. Dalam hal ini antara guru dan orang tua harus bekerjasama dalam bidang yang lebih luas seperti finansial, PMB, evaluasi, dll.

Dengan demikian kreativitas guru pendidikan jasmani sangat diperlukan dalam pelaksanaan proses pembelajaran di sekolah, dan guru juga harus mampu memperhatikan kualitas dari proses belajar mengajar di sekolah. Agar kaidah dan nilai pendidikan jasmani menjadi daya tarik maka guru pendidikan jasmani harus memiliki kreativitas pada proses pembelajaran ke siswa dengan menggunakan beberapa metode pembelajaran yang tapak, jelas dan informasi yang benar akan dapat menambah motivasi siswa untuk mengikuti pembelajaran pendidikan jasmani.

Berdasarkan keterangan diatas maka penulisan ini untuk meneliti hubungan dukungan orang tua terhadap motivasi berprestasi siswa SKOI Kalimantan Timur dalam mengikuti pembelajaran pendidikan jasmani.

\section{METODE}

Penelitian ini merupakan penelitian deskriptif kuantitatif yang bertujuan untuk mengetahui dukungan orang tua terhadap motivasi berprestasi siswa SKOI Kalimantan Timur dalam mengikuti pembelajaran pendidikan jasmani. Menurut Suharsimi Arikunto (2010: 3) bahwa Penelitian deskriptif merupakan penelitian yang bermaksud untuk memaparkan atau menggambarkan sesuatu hal, misalnya keadaan, kondisi, situasi, peristiwa, kegiatan, dan lainlain. Metode yang digunakan adalah survei, tekhnik pengambilan data menggunakan angket, skor yang diperoleh dianalisis menggunakan analisis diskriptif kuantitatif yang dituangkan dalam bentuk persentase.

Penelitian ini dilaksanakan di Sekolah Khusus Olahraga Internasional (SKOI) di Kota Samarinda. Pengambilan data dilaksanakan pada tanggal 2 November 2018 - 18 November 2018. Subjek penelitian ini adalah orang tua siswa dan siswa SKOI dengan jumlah 50 responden. Populasi adalah wilayah generalisasi yang terdiri atas: obyek/subyek yang mempunyai kualitas dan karateristik tertentu yang ditetapkan oleh peneliti untuk dipelajari dan 
kemudian ditarik kesimpulannya, (Sugiyono, 2013: 117). Populasi dalam penelitian ini adalah seluruh orang tua siswa dan siswa SKOI Kalimantan Timur.

Dalam penelitian ini menggunakan teknik sampling jenuh yaitu teknik penentuan sampel bila semua anggota populasi digunakan sebagai sampel (Sugiyono, 2013: 124), atau dengan kata lain penelitian ini adalah penelitian populasi dengan sampel seluruh orang tua siswa dan siswa SKOI Kalimantan Timur dengan jumlah 25 orang. Penelitian ini dilakukan untuk mengumpulkan data yang digunakan sebagai dasar untuk menetapkan kelayakan penelitian. Teknik dan instrumen pengumpulan data harus ditentukan secara tepat sehingga diperoleh data yang akurat sesuai dengan permasalahan dan tujuan penelitian.

Instrumen yang digunakan untuk mengumpulkan data pada penelitian ini berupa angket. Instrumen dipakai sebagai alat pengumpul data dari para ahli, guru dan siswa sehubungan dengan kritik, saran dan perbaikan yang bermanfaat bagi penelitian tersebut. Sebelum para ahli dan subyek mengisi angket untuk pengambilan data dijelaskan terlebih dahulu beberapa cara pengisian angket. Untuk memberi skor dari setiap pernyataan yang dijawab oleh responden dengan mencentang ya atau tidak. Dalam proses dukungan orang tua terhadap motivasi berprestasi siswa SKOI Kalimantan Timur dalam mengikuti pembelajaran pendidikan jasmani.

\section{HASIL DAN PEMBAHASAN}

\section{Analisis Data}

Teknik analisis data dalam penelitian ini menggunakan teknik statistik deskriptif yang dituangkan dalam bentuk persentase:

$P=\frac{f}{n} x 100 \%$

Keterangan:

$\mathrm{P}=$ presentase hasil

$f=$ frekuensi subyek

$\mathrm{n}=$ jumlah keseluruhan

Tabel 1. Norma Kriteria Penilaian

\begin{tabular}{cc}
\hline Nilai & Kategori \\
\hline $81-100 \%$ & Sangat Baik \\
$61-80 \%$ & Baik \\
$41-60 \%$ & Cukup Baik \\
$21-40 \%$ & Kurang \\
\hline $0-20 \%$ & Sangat Kurang \\
\hline
\end{tabular}

Data hasil penelitian tentang dukungan orang tua terhadap motivasi berprestasi siswa SKOI Kalimantan Timur dalam pelajaran pendidikan jasmani disajikan dalam bentuk kuesioner dukungan orang tua, untuk lebih jelasnya dapat dilihat pada tabel berikut ini: 
Jurnal Pendidikan Jasmani Indonesia, 14 (2), 2018- 66

Nanda Alfian Mahardhika, Jeane Betty Kurnia Jusuf, Galih Priyambada

Tabel 2. Dukungan orang tua

\begin{tabular}{|c|c|c|c|}
\hline \multirow[b]{2}{*}{ No } & \multirow{2}{*}{ Aspek Yang dinilai } & \multicolumn{2}{|c|}{ Pilihan Jawaban } \\
\hline & & Ya & Tidak \\
\hline 1 & $\begin{array}{l}\text { Apakah rang tua sibuk bekerja sehingga tidak pernah ada waktu luang } \\
\text { untuk membantu anda dalam belajar? }\end{array}$ & 50 & 0 \\
\hline 2 & $\begin{array}{l}\text { Apakah orang tua memuji ketika anda mendapatkan nilai ujian yang } \\
\text { baik? }\end{array}$ & 45 & 5 \\
\hline 3 & Apakah orang tua menanyakan perkembangan belajar anda? & 46 & 4 \\
\hline 4 & $\begin{array}{l}\text { Apakah orang tua perhatian dengan perkembangan nilai akademik Anda } \\
\text { di sekolah? }\end{array}$ & 44 & 6 \\
\hline 5 & Apa orang tua memberikan perhatian khusus ketika Anda akan ujian? & 44 & 6 \\
\hline 6 & $\begin{array}{l}\text { Apakah orang tua Anda memberikan informasi ketika Anda mengalami } \\
\text { masalah di sekolah? }\end{array}$ & 47 & 3 \\
\hline 7 & Apakah orang tua anda selalu memacu untuk terus giat belajar? & 49 & 1 \\
\hline & Apakah orang tua anda memberikan support anda ketika di rumah? & 47 & 3 \\
\hline & Apakah orang tua anda mendukung dalam mengembangkan bakat? & 46 & 4 \\
\hline & $\begin{array}{l}\text { Apakah orang tua menyiapkan sarana/fasilitas tambahan belajar untuk } \\
\text { anda? }\end{array}$ & 50 & 0 \\
\hline \multicolumn{2}{|r|}{$\begin{array}{l}\text { Jumlah Skor } \\
\text { Jumlah Maksimal Skor } \\
\text { Persentase Penilaian }\end{array}$} & $\begin{array}{c}468 \\
500 \\
93,4 \%\end{array}$ & $\begin{array}{c}32 \\
500 \\
6,6 \%\end{array}$ \\
\hline \multicolumn{2}{|c|}{ Kategori } & $\begin{array}{c}\text { Sangat } \\
\text { Baik }\end{array}$ & $\begin{array}{l}\text { Sangat } \\
\text { Kurang }\end{array}$ \\
\hline
\end{tabular}

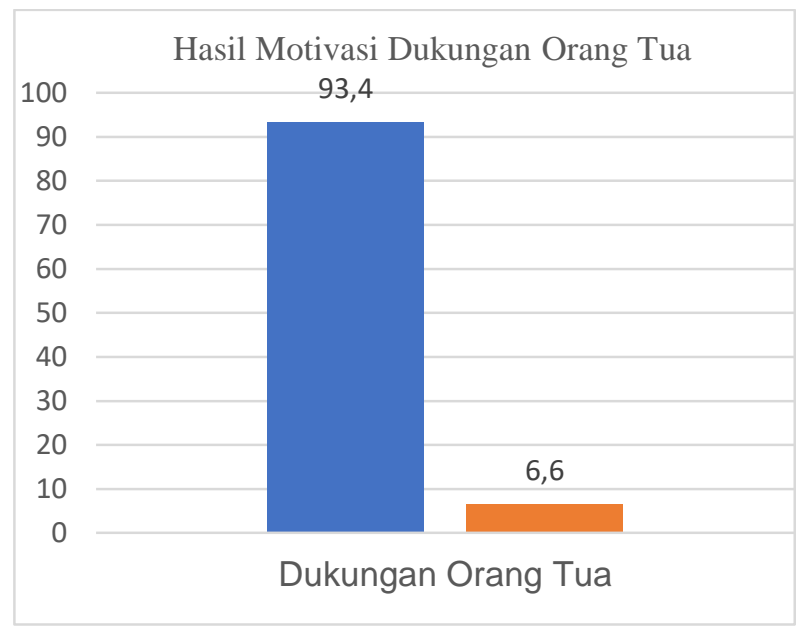

Gambar 1. Hasil motivasi dukungan orang tua

Berdasarkan tabel dan diagram diatas, dapat dijelaskan sebagai berikut:

1. Penilaian dukungan orang tua terhadap motivasi berprestasi siswa SKOI Kalimantan Timur dalam mengikuti pembelajaran pendidikan jasmani yang menjawab ya pada aspek tampilan menunjukkan bahwa dalam kategori sangat baik, dengan persentase 93,40\%.

2. Penilaian dukungan orang tua terhadap motivasi berprestasi siswa SKOI Kalimantan Timur dalam mengikuti pembelajaran pendidikan jasmani yang menjawab tidak pada aspektampilan menunjukkan bahwa dalam kategori sangat baik, dengan persentase $6,60 \%$.

Berdasarkan hasil pengisian angket hubungan dukungan orang tua terhadap motivasi berprestasi siswa SKOI Kalimantan Timur dalam mengikuti pembelajaran pendidikan jasmani pada ketegori sangat baik dengan persentase 93,40\%. 
Jurnal Pendidikan Jasmani Indonesia, 14 (2), 2018- 67

Nanda Alfian Mahardhika, Jeane Betty Kurnia Jusuf, Galih Priyambada

Tabel 3. Motivasi Berprestasi

\begin{tabular}{|c|c|c|c|}
\hline \multirow{2}{*}{ No } & \multirow{2}{*}{ Aspek Yang dinilai } & \multicolumn{2}{|c|}{ Pilihan Jawaban } \\
\hline & & Ya & Tidak \\
\hline 1 & Apakah Anda selalu membaca buku pelajaran pendidikan jasmani? & 49 & 1 \\
\hline 2 & $\begin{array}{l}\text { Apakah Anda selalu mendengarkan penjelasan dari guru tentang } \\
\text { pendidikan jasmani? }\end{array}$ & 50 & 0 \\
\hline 3 & $\begin{array}{l}\text { Apakah Anda tetap belajar meskipun dapat nilai mata pelajaran } \\
\text { pendidikan jasmani bagus? }\end{array}$ & 50 & 0 \\
\hline 4 & $\begin{array}{l}\text { Apakah Anda bersungguh-sungguh dalam mengikuti pembelajaran } \\
\text { pendidikan jasmani di sekolah? }\end{array}$ & 46 & 4 \\
\hline 5 & $\begin{array}{l}\text { Apakah Anda melakukan aktivitas jasmani sendiri pada saat libur } \\
\text { sekolah? }\end{array}$ & 44 & 6 \\
\hline 6 & $\begin{array}{l}\text { Apakah Anda bertanya kepada guru pendidikan jasmani ketika Anda } \\
\text { tidak memahami materi yang diajarkan oleh guru? }\end{array}$ & 47 & 3 \\
\hline 7 & $\begin{array}{l}\text { Apakah Anda senang dan nyaman ketika pembelajaran pendidikan } \\
\text { jasmani? }\end{array}$ & 50 & 0 \\
\hline 8 & $\begin{array}{l}\text { Apakah Anda diskusi dengan dengan orang tua dan guru tentang } \\
\text { kebugaran jasmani anda? }\end{array}$ & 50 & 0 \\
\hline 9 & $\begin{array}{l}\text { Apa Anda berlomba-lomba untuk mendapatkan nilai baik pada } \\
\text { pembelajaran pendidikan jasmani di sekolah? }\end{array}$ & 50 & 0 \\
\hline & $\begin{array}{l}\text { Apakah Anda ingin mendapatkan hasil yang baik pada ujian semester } \\
\text { pendidikan jasmani? }\end{array}$ & 50 & 0 \\
\hline \multicolumn{2}{|r|}{$\begin{array}{l}\text { Jumlah Skor } \\
\text { Jumlah Maksimal Skor } \\
\text { Persentase Penilaian }\end{array}$} & $\begin{array}{c}486 \\
500 \\
97,2 \%\end{array}$ & $\begin{array}{c}14 \\
500 \\
\mathbf{2 , 8} \%\end{array}$ \\
\hline \multicolumn{2}{|c|}{ Kategori } & $\begin{array}{l}\text { Sangat } \\
\text { Baik }\end{array}$ & $\begin{array}{l}\text { Sangat } \\
\text { Kurang }\end{array}$ \\
\hline
\end{tabular}

Berdasarkan tabel di atas, jika ditampilkan dalam bentuk diagram hasilnya dapat dilihat sebagai berikut:

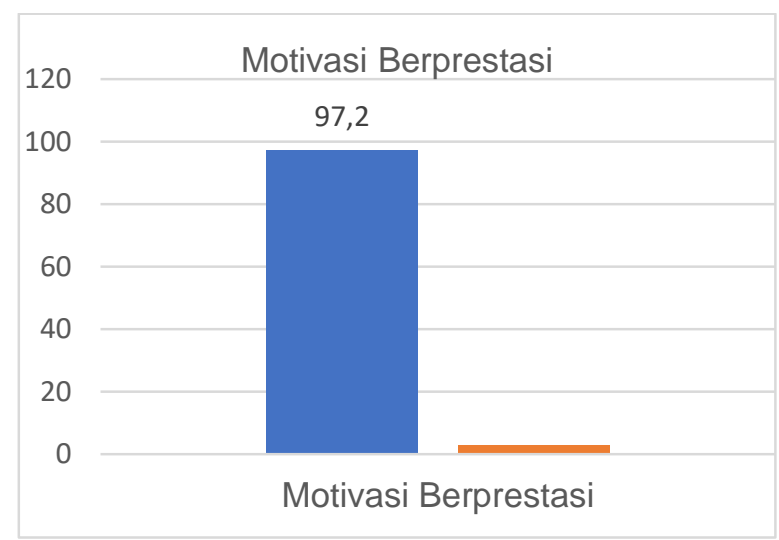

Gambar 2. Motivasi Berprestasi

Berdasarkan tabel dan diagram diatas, dapat dijelaskan sebagai berikut

1. Penilaian motivasi berprestasi siswa SKOI Kalimantan Timur dalam pembelajaran pendidikan jasmani yang menjawab ya pada aspek tampilan menunjukkan bahwa dalam kategori sangat baik, dengan persentase $97,20 \%$.

2. Penilaian motivasi berprestasi siswa SKOI Kalimantan Timur dalam pembelajaran pendidikan jasmani yang menjawab tidak pada aspek tampilan menunjukkan bahwa dalam kategori sangat baik, dengan persentase 2,80\%.

Berdasarkan hasil pengisian angket motivasi berprestasi siswa SKOI Kalimantan Timur dalam pembelajaran pendidikan jasmani pada ketegori sangat baik dengan persentase $97,20 \%$. 


\section{SIMPULAN}

Berdasarkan hasil penelitian dan pembahasan yang dipaparkan dan ditulis peneliti maka dapat disimpulkan bahwa dukungan orang tua terhadap motivasi berprestasi siswa SKOI Kalimantan Timur dalam pembelajaran pendidikan jasmani dalam kuesioner dukungan orang tua termasuk kedalam kategori sangat baik yaitu dengan jumlah 468 butir soal yang menjawab iya atau sebesar $93,40 \%$. Dalam kuesioner motivasi berprestasi termasuk kedalam kategori sangat baik yaitu dengan jumlah 486 butir soal yang menjawab iya atau sebesar $97,20 \%$. Hasil tersebut dapat disimpulkan bahwa dengan mendapatkan dukungan dari orang tua mereka maka prestasi siswa SKOI Kalimantan Timur dalam mengikuti pembelajaran pendidikan jasmani akan meningkat dan juga dengan mendapatkan dukungan dari orang tua siswa SKOI Kalimantan Timur dalam pembelajaran pendidikan jasmani mendapatkan hasil/nilai yang baik pada saat ujian semester di sekolah.

\section{DAFTAR PUSTAKA}

Rozaqoh, L. (2008). Hubungan Antara Dukungan Orang Tua Dengan Motivasi Belajar Remaja. Jurnal Psikosains. 1 (3).

Paramitha, S.T., Anggara, L.A. (2018). Revitalisasi Pendidikan Jasmani untuk Anak Usia Dini melalui Penerapan Model Bermain Edukatif Berbasis Alam. UPI. Jurnal Pendidikan Jasmani dan Olahraga. 3 (1)

Putri, E.P. (2014). Hubungan Dukungan Sosial Orang Tua, Pelatih dan Teman dengan Motivasi Berprestasi Akademik dan Motivasi Berprestasi Olahraga (Basket) Pada Mahasiswa Atlet Basket Universitas Surabaya. Jurnal IImiah Mahasiswa Universitas Surabaya. 3 (1).

Rosyidah,U.M. (2017). Dukungan Sosial Orang Tua Dengan Motivasi Belajar Siswa Putra Tahfidz Al-Qur'an. Jurnal Psikologi Islami. 3 (2).

Sudijono. A (2012). Pengantar Evaluasi Pendidikan. Jakarta: PT. Raja Grafindo Persada

Sugiyono. (2013). Metode Penelitian Pendidikan. Bandung: Alfabeta

Arikunto, Suharsimi. 2010. Prosedur Penelitian Suatu pendekatan Praktek. Jakarta: Rineka Cipta.

Suryobroto, A. S. (2004) Peningkatan Kemampuan Manajemen Guru Pendidikan Jasmani. Jurnal Pendidikan Jasmani Indonesia. 1 (1).

Syahrin, A., Amiruddin., Bustamam. (2017). Peran Guru Pendidikan Jasmani Dalam Membentuk Karakter Siswa Pada Mts Se-Banda Aceh Tahun Pelajaran 2016/2017. PJKR: FKIP Unsyiah. Jurnal. 3 (2).

Undang-Undang Republik Indonesia Nomor 20 Tahun 2003 Tentang Sistem Pendidikan Nasional. 